\title{
An Evaluation of Graduate Competency in Elementary School
}

\author{
Moch. Bahak Udin By Arifin \\ Fakultas Agama Islam \\ Universitas Muhammadiyah \\ Sidoarjo \\ Sidoarjo, Indonesia \\ bahak.udin@umsida.ac.id
}

\author{
Pandi Rais \\ Program Pendidikan Islam \\ Sekolah Tinggi Agama Islam Negeri \\ Kediri \\ Kediri, Indoonesia \\ Pandirais.10@gmail.com
}

\author{
Nurdyansyah \\ Fakultas Agama Islam \\ Universitas Muhammadiyah \\ Sidoarjo \\ Sidoarjo, Indonesia \\ nurdyansyah@umsida.ac.id
}

\begin{abstract}
In the Law on the National Education System in Indonesia explains about the eight national standards of education, which is position the competence of graduates as the center of the displacement of eight national standards of education. All power were intended to support the development of the standard of learning mastery quality contained in knowledge, skills and attitudes. Applying the standard of learning mastery was not as good as expected, many obstacles encountered. Not a few elementary schools, educators, and educational personnel who have limited understanding and skills in applying this standard. Most of elementary school have not understand the essence of the standard of learning mastery and the correlation with others standard yet. As the result, the process of preparing the standard of learning mastery only for fulfil the administrative requirement. The objective of this research was to know the implementation of the standard of learning mastery in elementary school. The research method was qualitative of description. The results of this research were: a) Lack of school of academic achievement and non-academic achievement both at national and international level, b) there was no design for improving students of postgraduate in academic or nonacademic, c) preparing rule by school for growing interest and talent students up.
\end{abstract}

Keywords-the standard of learning mastery; elementary school

\section{INTRODUCTION}

Education is always as spotlight many people, not only from policy holder but also user (students). Nowadays and the future to be challenge is increasing the quality of education based on the standard.

To create it cannot one or two years only but it needs a continuous process [1]. The eight standards of education implement in elementary school. But with the current demands of the quality of education is increasing we need to review again whether the minimum standard in elementary school is running according to minimum standards of provision
As a follow up of the enactment of the Law on the National Education System, the government set up the Indonesian Government Regulation on National Education Standards. In Government Regulation the National Education Standards are the minimum criteria of the education system throughout the jurisdiction of the Unitary Republic of Indonesia. National Education Standards serve as a basis in the planning, implementation, and supervision of education in order to realize a quality national education. The objective of SNP is to ensure the quality of national education in order to educate the nation's life and shape the character [2], [3], [4]; and civilization of a beneficial nation.

In Law No. 20 of 2003 on National Education System article 35 [5] explains that the quality of national education in Indonesia should have eight minimum standards, covering 1) content standards, 2) processes, 3) graduate competencies, 4) educators and education, 5) facilities and infrastructure, 6) management, 7) financing, and 8) educational assessments that should be improved on a planned and periodic basis.

The focus of long-term education development is directed at strengthening the implementation of the 8 National Education Standards as the minimum standards that must be achieved in each educational unit. Especially from the standard of learning mastery which is still not mapped well.

The standard of learning mastery should be positioned as the center of the dynamic movement of all resources [6]. All the power directed to support for developing quality of the standard of learning mastery realized in knowledge, skills and attitude. The main component of the standard of learning mastery is the learning standards consisting of subject matter, learning process, and assessment.

The effectivity of learning determined between educators and educational staff, facilities and infrastructure, and cost. To shape all standards componence in leading to the achievement of the standard of learning mastery quality, so the schools have to develop the planning system, implementing, and evaluating all quality improvements to all standards integrated into the competency standards of graduates.

The standard of learning mastery position which is in eighth from the lowest order in educational national standard. 
Thus, this research was done to know the reasons behind low causing of the standard of learning mastery. As the result, the recommendation could be formulated to increase the standard of learning mastery in students of elementary school.

\section{METHOD}

Method of this research used qualitative of description [7], [8], [9]; with some logic consideration. Firstly: qualitative method more effective to analyze implementation problems. Secondly: It is effectively to learn the implementation of the standard of learning mastery. Thirdly: It provides a great opportunity to understand and seek the meaning of a problem. Fourthly: There is subjectivity inside the implementation, thus it must be understood by their own understanding and utterance (this aspect is for headmaster [10], vice and stake holders, so it must be understood by qualitative method.

\section{RESULT AND DISCUSSION}

The successful of performance in education implementation can be measured if-and-only-if measurement and the objectives of the policy are indeed realistic with sociocultures that are at the educational level [11]. When the measurement and the objectives of education ideal overly to be held in schools' level, so it would be difficult to hold the policy and implementation till success. To make sure the successful of implementation, we must determine the number of jobs that have been made, the identity of those who have been hired, and the progress on the related works [5]. From some cases, the standard and objective of the studies must be concluded by researcher only. One more, the researcher might be wanted to apply the criteria based on society or schools in evaluating of education [12], [13], [14]. In the end, the choice of measurement performance based on the objective of the research [15].

Inadequate of school in reaching academic or nonacademic achievement not only national but also international level, based on the result of research shown; inadequate of school in achieving art and culture [16] competition (dancing, crafting, painting, batik, music, theater which only achieve $24 \%$ in implementation). This result was comparable to the results of field interviews stating that schools are still very rare who won trophies in the arts and culture. Eventhough the school had already done some extracurricular, the result was not as goos as target study. The school seldom deligated their students in competition but it was only in region or city level only. Lacking of extracurricular or students organisation on one last year, it was only achieved $30 \%$. It was only some schools in achieving the winner in region or city level. Lowing the school in achieving championship and consellng service competition (such as; career planning, private life, social skill, etc); and/or extracurricular activity (for example: scout, leadership exercises, nature lovers, journalism, social service, etc., whose real value was only $40 \%$. The result of questionaire and interviewed could be achieved the reasons why schools rarely get the championship counseling service competitions because there was still no synergy between the activities undertaken schools with the development of student competence. The lack of schools had the highest level of participation in the enforcement of social rules such as socialization of discipline, drug counseling, juvenile delinquency counseling, record of violations, sanction records, etc. in the past year only reached a low of $27 \%$. From the result observation and inerviewed could be got that the school had not intent yet in delegation their students to do drug counseling, juvenile delinquency and others. The lack of School got the highest championship in the field of student participation in the society, nation and democratic state in the NKRI, such as the ceremony of the State Day, PMR, students organisation activities and others which only reached $27 \%$. The school became the winner was in low for shaping students characteristic, growing the sportivity up, and environmental Hygiene, such as; $7 \mathrm{~K}$ programme, hygine competition of each classes, related local content and so on which only achieved $20 \%$. Besides, the championship for religion and good attitude which was affectively, were in low condition, like; worship, learning scripture, Qiroah and reading holy Qur'an and etc. Its value was only 1,17 or $29 \%$. Schools received the highest accolade in self-development from programmed and nonprogrammed counseling and / or extracurricular activities such as counseling services, flag ceremonies, worship, karma in action, etc. that only reached 0.58 or $15 \%$. The school got higest appreciation in respecting different opinion and empathy each other, for example; group discussion, seminar, workshop, discussion, debat and etc that was only calculated 0,83 or $21 \%$.

Not only academic and non-academic achievement, schools also rarely did self-development services on their students. It was evident from the results of research showed that the value in the achievement of self-development services to students was only $15 \%$. So, the school was still not maximized in optimizing the potential of students both in terms of academic and non academic until now. As a result of statistics stated that self-development services in students only reached $15 \%$ only.

\section{CONCLUSION}

Some factors causing students in lowing achievement the standard of learning mastery; 1). Lacking of achieving the higest competition for the school; 2) developing art and culture, extracurricular and students organisation; 3) counseling service (ex: career plan, private life, social skill, etc) ; 4) Lowing in carry out the social laws such as: code of cunduct; 5) inevenly drug conseling, juvenile delinquency, violation and witness record, etc; 6) lowing students participation; 7) religion aspect and good attitute were not affective, for example: gatherness in worship activities, learning scripture, Qiroah, reading Qur'an, etc; 8) selfdevelopment service like counseling and/or ekstracurricular; 9) lacking sportivity, respect diffrent opinion and empathy to others, for example group discussion, workshop, discussion, and students' debat.

Implementation the standard of learning [17] mastery in elementary school only achieved $0,58 \%$. If the reseacher analyzed this value as a whole, it was very low value. If the reseacher had compared with accreditation value, it would have got $\mathrm{C}$ (enough) value. 
Some problems behind this problem were: the shcool accompaniment was not actively and intently in some district till international competition yet, and the school was low in delegated their studets to compete in academic or nonacademic competition. The main cause was limited costs and potential learners who have not maximized.

The guarantee of execution the standard of learing mastery in schools had already done accordingly to the procedures, such as the implementation of talent development of students in schools with extracurricular activities, subject guidance and others.

Suggestions and Recommendations to improve the quality of the standard of learning mastery implementation There needs to be an intensive school assistance and student delegation of various competitions in the city, national and international. There should be extracurricular activities and self-development of students programmed and do coaching in schools in the district of Sidoarjo so that students who have academic and non academic talents can run optimally

Religious field development needs to be intensified not only culture but also the provision of a continuous understanding both within the classroom and outside the classroom. So the students have a complete understanding.

\section{ACKNOWLEDGMENT}

This research was supported by Faculty of Islamic Studies Universitas Muhammadiyah Sidoarjo, Bappeda of Sidoarjo, East Java, Indonesia and research and community service institute of Universitas Muhammadiyah Sidoarjo.

\section{REFERENCES}

[1] Carolin Kreber, Paula Brook \& Educational Policy, "Impact evaluation of educational development programmes," International Journal for Academic Development, Vol.6, Issue 2, pp. 96-108.

[2] Rahmi Fahmy, Nasri Bachtiar, Rida Rahim, Melini Malik, "Measuring Student Perception to Personal Characters Building in Education: An Indonesian Case in Implementing New Curriculum in High School," Procedia Social and Behavioral Science, Vol. 211, November 2015, pp. 851-858.

[3] Fathur Rokhman, M. Hum, Ahmad Syaifudin, Yuliati, "WCharacter Education for Golden Generation 2045 (National Character Building for Indonesian Golden Years)," Procedia - Social and Behavioral Sciences, Vol. 141, August 2014, pp. 1161-1165.
[4] Erick Ferdiawan, Wira Eka Putra, "Esq Education for Children Character Building based on Phylosophy of Javaness in Indonesia," Procedia - Social and Behavioral Sciences, Vol. 106, December 2013, pp. 1096-1102.

[5] Undang-Undang Nomor 20 tahun 2003 tentang Standar Pendidikan Nasional.

[6] Satu Kajander-Unkuri, Riitta Meretoja, Jouko Katajisto, Mikko Saarikoski, Leena Salminen, Riitta Suhonen, Helena Leino-Kilpi, "Selfassessed level of competence of graduating nursing students and factors related to it," Nurse Education Today, Vol. 34, Issue 5, May 2014, pp. 795-801.

[7] Lexy J. Moloeng, "Metodologi Penelitian Kualitatif," Bandung: Remaja Rosda Karya, 2000.

[8] Leo Appleton, "Chapter Seven: Qualitative Methods for Performance Measurement," Libraries and Key Performance Indicators, 2017, pp. 4756.

[9] Keith R. Mcvilly, Roger J. Stancliffe, Trevor R. Parmenter, Rosanne M. Burton-Smith, "Remaining Open to Quantitative, Qualitative, and Mixed-Method Designs: An Unscientific Compromise, or Good Research Practice?," International Review of Research in Mental Retardation, Vol 35, 2008, pp. 151-203.

[10] Nicholas C. Bedard, "The strategically ignorant principal," Games and Economic Behavior, Vol. 102, March 2017, pp. 548-561.

[11] Kevin Patton, Melissa Parker, "Teacher education communities of practice: More than a culture of collaboration," Teaching and Teacher Education, Vol. 67, October 2017, pp 351-360.

[12] Navid Ghaffarzadegan, Yi Xue, Richard C. Larson, "Work-education mismatch: An endogenous theory of professionalization," European Journal of Operational Research, Vol. 261, Issue 3, September 2017, pp. 1085-1097.

[13] Annemarieke Hoekstra, Jocelyn R. Crocker, "Design, implementation, and evaluation of an ePortfolio approach to support faculty development in vocational education," Studies in Educational Evaluation, Vol. 46, September 2015, pp.61-73.

[14] Hsu-Chan Kuo, Pamela Burnard, Ros McLellan, Ying-Yao Cheng, JingJyi $\mathrm{Wu}$, "The development of indicators for creativity education and a questionnaire to evaluate its delivery and practice," Thinking Skills and Creativity, Vol. 24, June 2017, pp. 186-198.

[15] D.S Van Meter and C. E Van Horn, "The Policy Implementation Process: A Conceptual Framework," Administration and Society, 1975.

[16] Ari Widyanti, Lusi Susanti, Iftikar Zahedi Sutalaksana, Khoirul Muslim, "Ethnic differences in Indonesian anthropometry data: Evidence from three different largest ethnics," International Journal of Industrial Ergonomics, Vol. 47, May 2015, pp. 72-78.

[17] Lisette Wijnia, Eva M. Kunst, Marianne van Woerkom, Rob F. Poell, "Team learning and its association with the implementation of competence-based education," Teaching and Teacher Education, Vol. 56, May 2016, pp. 115-126. 